院含/DCOJUSIOS

\title{
ポステリア・サポートを回復する上で下顎位をどう捉えるべきか 〈低位珓合を改善した症例を通して〉
}

梶川直裕

Consideration of Mandibular Position, when

Posterior Support is Recoverd

Naohiro Kajikawa

長年口腔内の環境を不良な状態のまま放置してのち，いよいよ咬めないということで来 院する患者の多くが臼歯部の咬合崩壞による低位咬合という問題を抱えていることに気付 く、そしてその多くは多数歯欠損を伴い, 結果として残存歯に外傷性の咬合力が加わり歯 の移動や歯周疾患の進行を加速させてしまう状態をよく見かける。また顎関節症様の症状 を呈する方も少なくない.

治療にあたってはポステリア・サポートの回復がもっとも重要な作業になるわけである が，その際「下顎位をどう捉えるか」がいかに術後経過に大きく影響しているかは言うま でもないことである。そこで実際の臨床の中でこの問題にどのように関わっていくべきか 過去と現在の二症例を提示し検討することとする。 

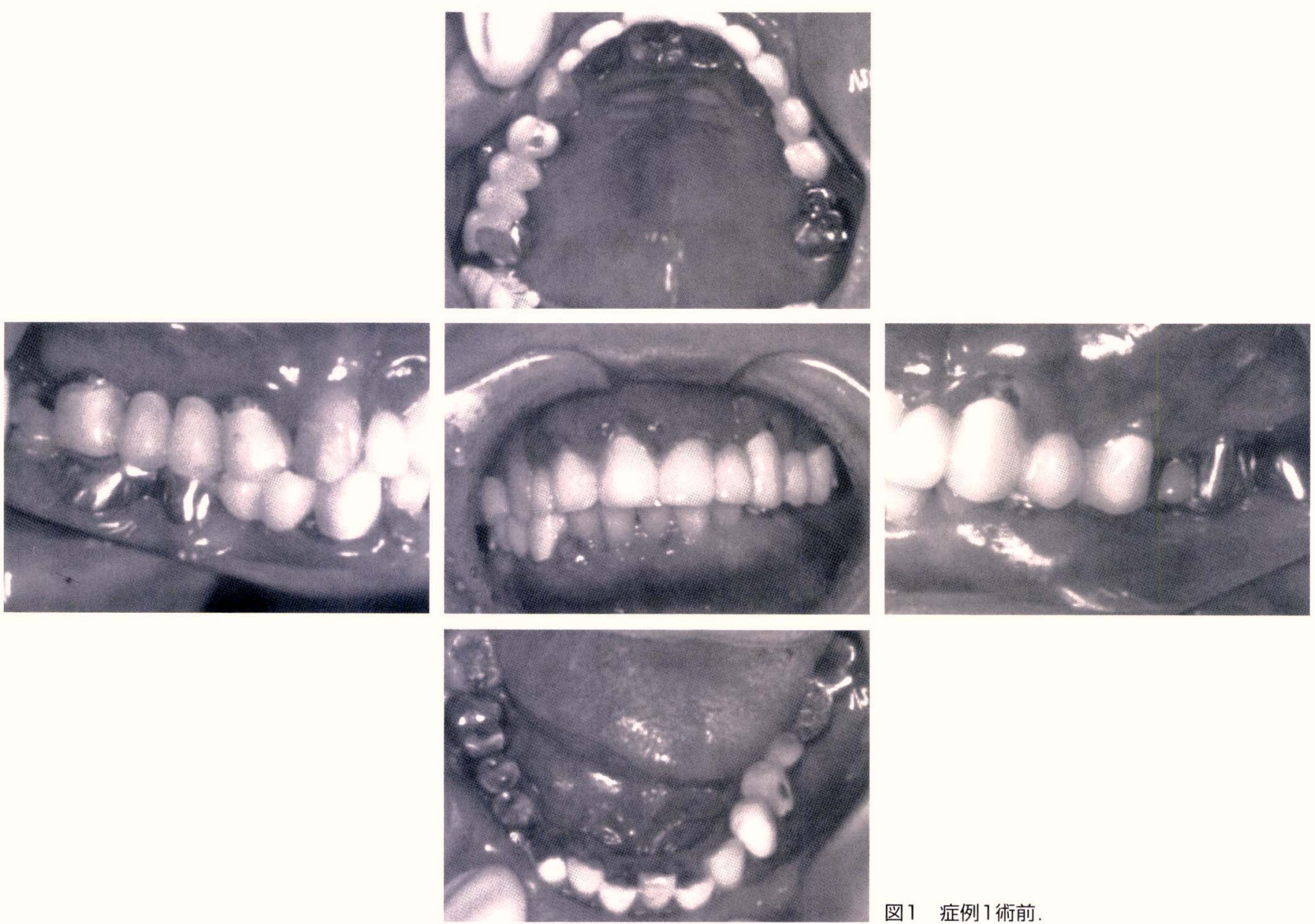

図 1 症例 7 術前。

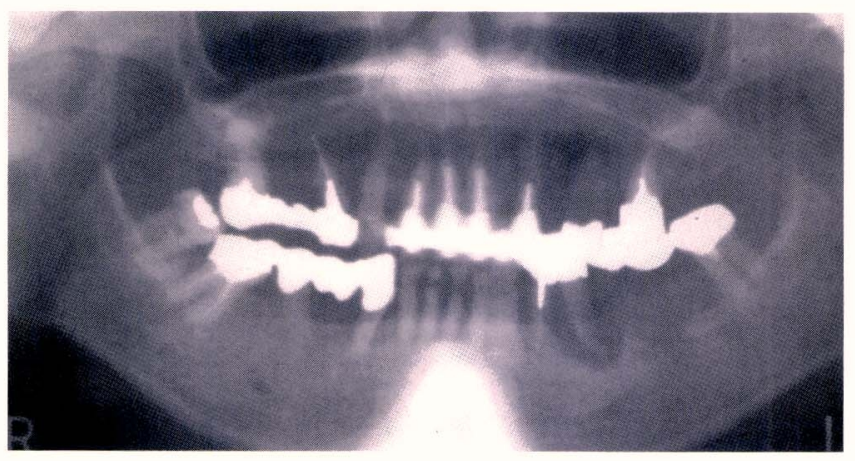

症例 1

年齢：初診時53歳

性別：女性

職業：主婦

主訴：他院にて 2 年前全体的な治療を受けたが最近とにか く咬めない，咬んでいると頭が痛くなる.
図2 症例 1術前パノラマX線写真.

\section{口腔内所見}

多数歯の欠損を始めとし歯・歯周組織・咬合すべてに問 題を抱えているように見受けられ，一見して低位咬合を疑 うに十分な臼歯部による咬合支持関係の不全が非常に印象 的な状涊であった (図 1，2). 

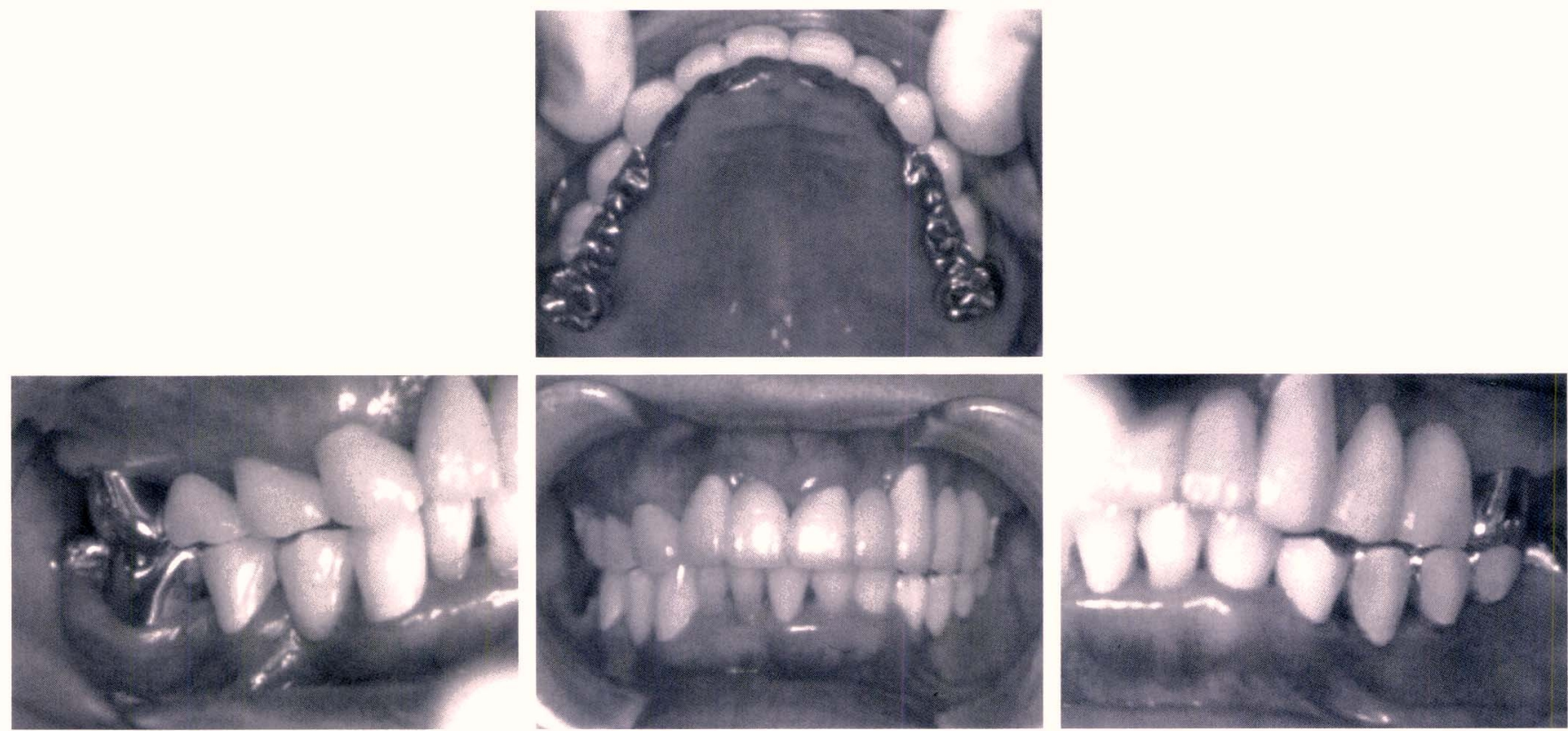

図3 症例 7 術後.

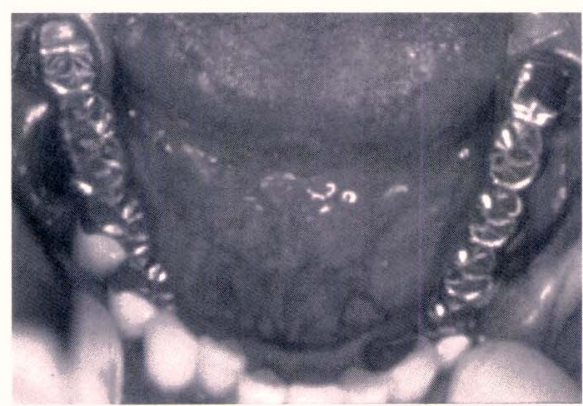

図4 症例1術後パノラマX線写真

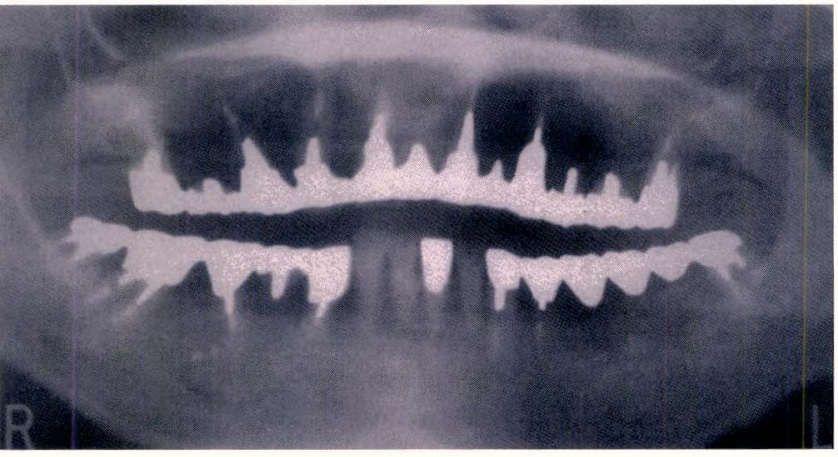

\section{治療内容と術後経過}

このままでは補綴物を装着するスペースすらない状況 で，とにかくポステリア・サポートを回復させ主訴の改善 をはかることをめざし治療を進めることとした。

結果的に補綴物を装着するスペースが確保され主訴は改 善し，無事修復は終了したが，定期検診時にメインテナン スをさせていただくたびに，歯の位置関係や歯周組織の改
善，欠損補綴など柬周補綴という考えのもと，もっと予知 性の高い治療の選択肢を選ぶべきであったと反省させられ ることとなった(図3，4).

反面，なぜ術後たった 2 年で咬合崩壊を起こした症例が 幸いわずか 5 年弱ではあるが大きな問題も発生することな く無事過ごせているのかという疑問も起こってしかるべき ことである。この症例において術前と術後を比較してみる と,「咬合高径とくに左側臼歯部の咬合高径が著しく変化 

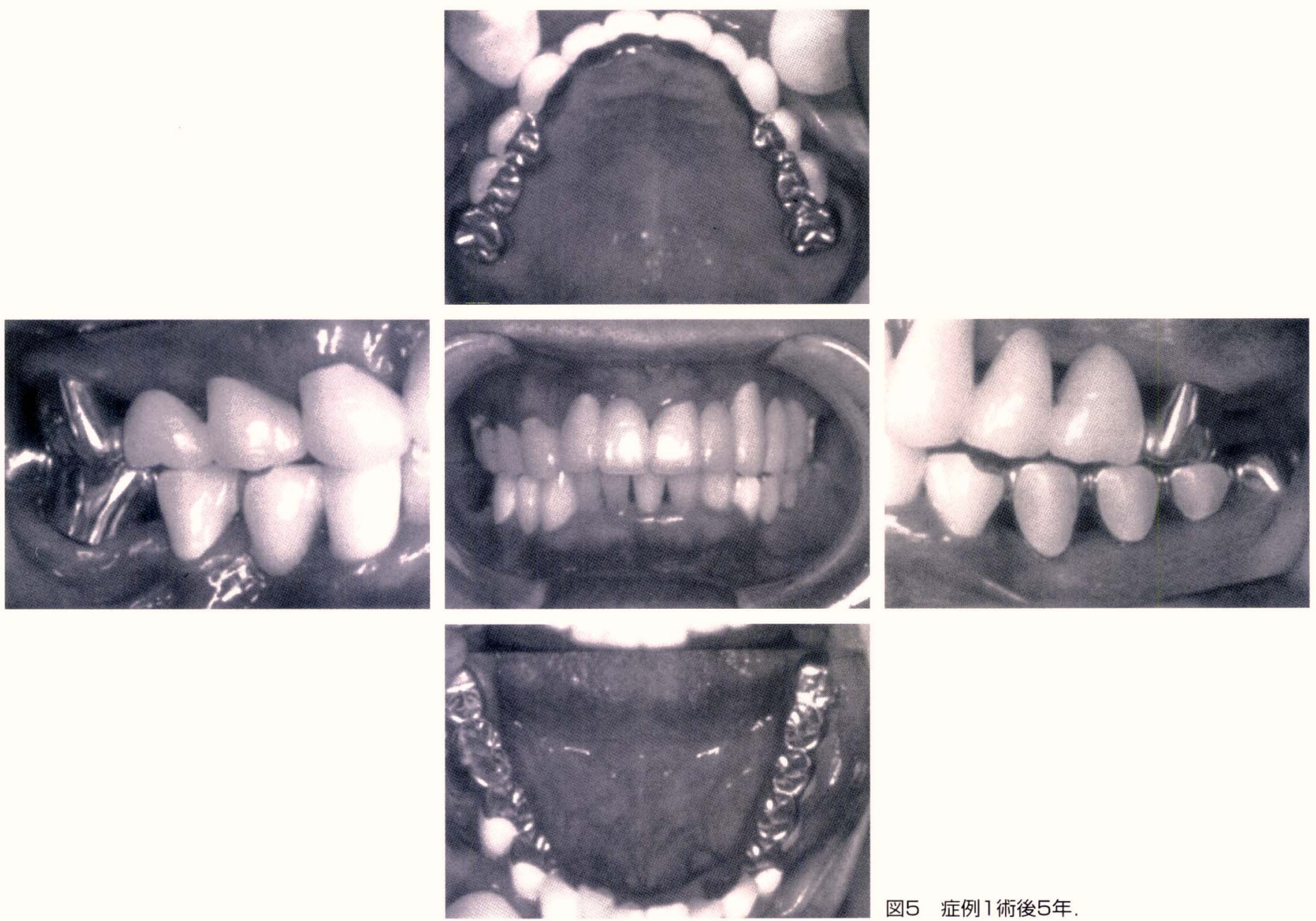

図5 症例 1 術後5年
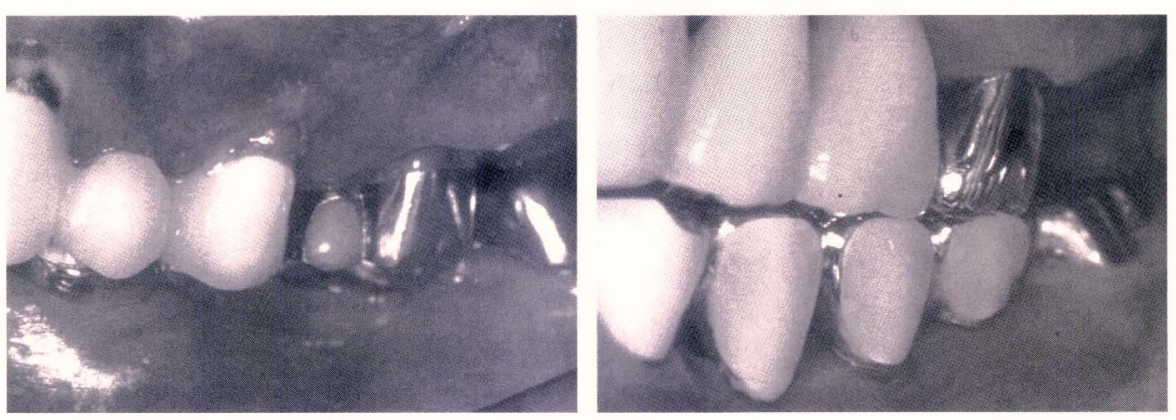

図6 左側臼歯部の咬合高径の变化

左：術前, 右 : 術後

している」ことに気付く。そこでこのことがこの疑問に対 する答えに大きく関わっているであろうと推測した(図5, 6).

この症例では術前において「顆頭の変位を伴った低位咬 合」であったと推測されるが，ポステリア・サポートの回 復をすすめるなかで，たまたま運良く下顎位が安定し，そ の結果低位咬合は改善した。そのことが良好な術後経過に 寄与していたのであろうと考えた。
症例 1 をきっかけに日頃よく耳にする「予知性の高い治 療をめざして」という言葉のもとインプラント治療や歯周 外科などに興味を持ち積極的に取り組むようになった。同 時に日常臨床の中で「下顎位をどう捉えるか，咬み合わせ を診る」ということが術後経過に非常に大きく関わってい ることを再認識することにもなった。

それでは症例 1 の反省点をふまえて現在のこの問題に対 する取り組みについて今年の学会のメインテーマである 「歯周病と咬合」に関わる症例発表を通じて報告する。 

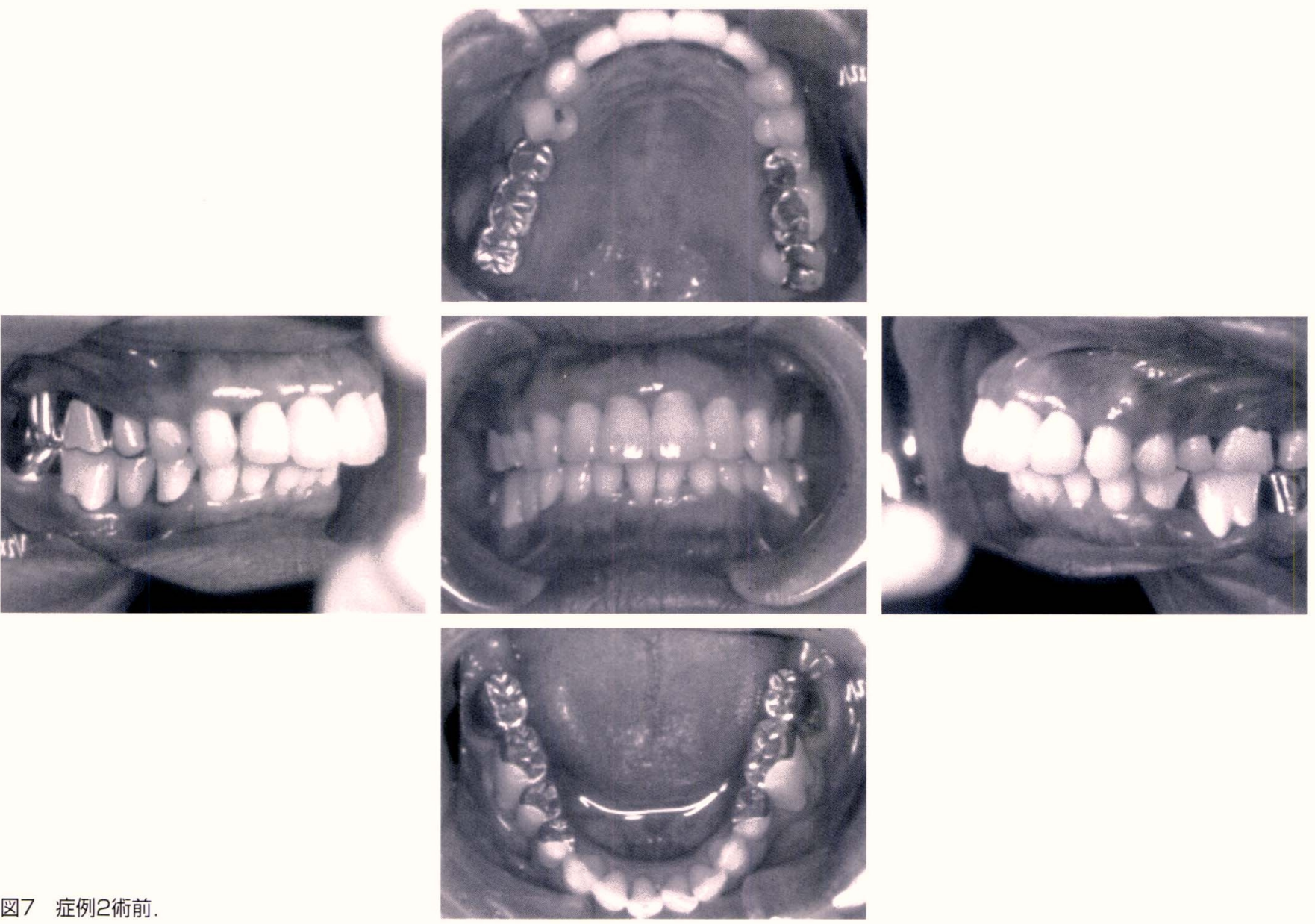

図8 初診時4のX線像

· 白線の消失

·支持骨の希薄化

・明瞭な骨吸収像

・プロービング・デプス 最深部で $4 \mathrm{~mm}$

·明瞭な歯石の残留なし

·動摇度2度

・コンタクトカリエスあり
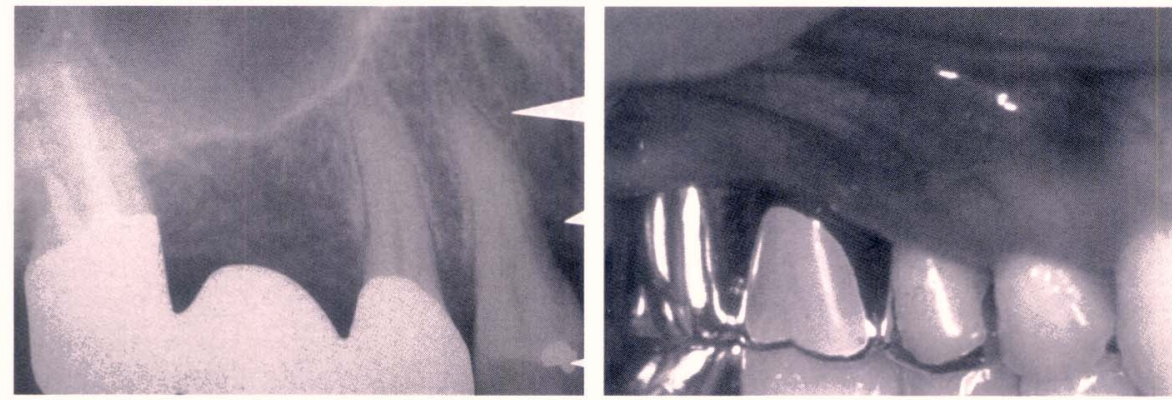

\section{症例 2}

年齢：初診時 47 歳

性別：女性

職業：歯科助手 (他院)

主訴：右上 4 が動摇して強くかむと痛い，前歯が大きく見 えるのできれいにしてほしい(図7)

\section{口腔内所見}

右上 4 周井の X 線所見は図8の通りである.
職業柄，口腔内の自己管理のレベルは非常に高く，「上 顎第 1 小臼歯近心側根面の解剖学的形態ゆえに起こりがち な問題」を差し引いても，単に口腔衛生状態の管理のみに 原因老求めるのには抵抗がある。しかし，近心側の垂直性 の骨吸収など歯周疾患を加速させる原因として咬合が関 わっている疑いが非常に強いものの，口腔内所見において は，強い側方力を発生させるような咬頭干渉は見当たらず， 咬頭嵌合位では左右の咬合接触は比較的良好で，咬合の不 安定さは感じられないように見受けられた。 

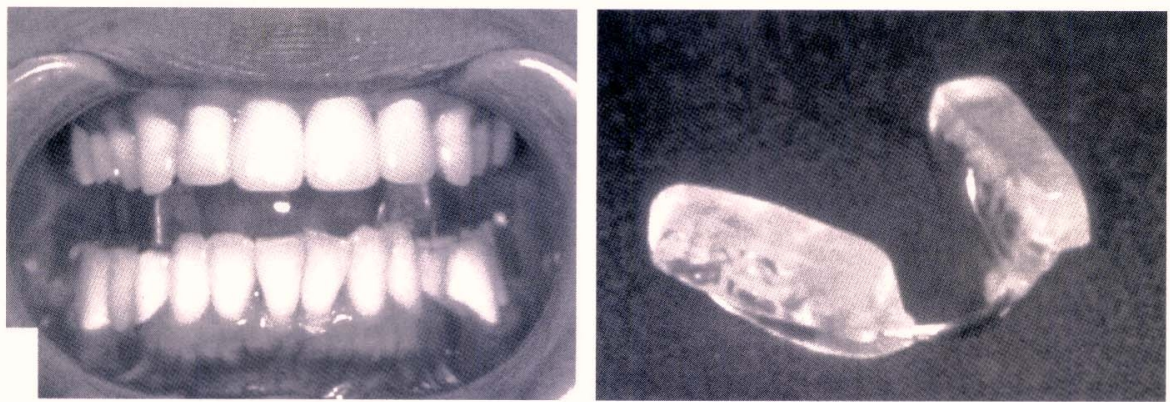

図9 オクルーザル・スプリントを用いて下顎 位の安定を回復する，夜間装着していただき咀 嚼筋のリラクゼーションをはかる.

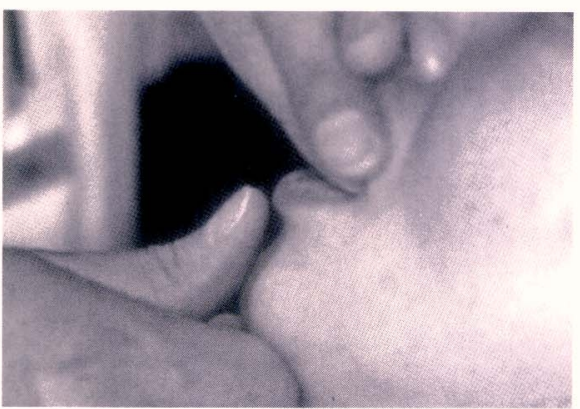

図10 チン・ポイント変法，手指はあくまで 下顎を誘導するものであって力を加えるもので はない，親指は誘導を円滑に進めるために軽く 添える.

\section{治療内容と術後経過}

そこで症例 1 における反省をふまえ，まずは下顎位の安 定をはかりその上で咬合診断を行い，下顎位が安定してい ることを確認し，もし安定していなければ何が原因である かを精査することとした。

はじめに下顎位の安定を得るため，臼歯部被覆型スプリ ントを夜間使用していただき，非機能時の歯牙接触による 弊害を取り除き咀嚼筋のリラクゼーションをはかった。こ のスプリントは下顎臼歯部に装着しフラットな面の上に上 顎臼歯の舌側咬頭頂が均等に接触するようにチン・ポイン 卜変法を用いて咬合接触を調整したものである。何度か繰 り返し調整した後，スプリントの咬合接触に変化が生じな くなったことをもって下顎位の安定が得られたと判断しな (図9, 10).

いよいよ，咬合診断に移ることとした。中心位の咬合採 得においてはスプリントの調整と同様にチン・ポイント変 法を用い，咬合接触の無い状態でしかもできるだけ近接し た位置で上下顎歯列の位置関係をシリコーン製咬合記録材 にて記録する。

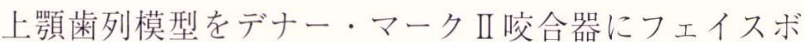
ウ・トランスファーした彴，下顎歯列模型のマウントに際
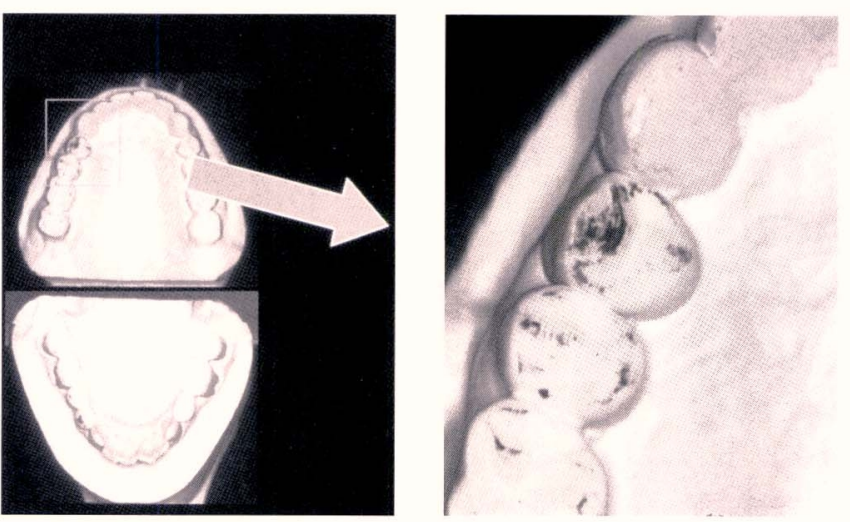

図13 早期接触.

しては中心位の咬合採得を 3 度行い，スプリット・キャス トを用いて同一下顎位が再現されていることをまず確認し た。スプリット・キャスト法は同一下顈位を再現している か否かを判断するには非常に精度の高い方法である。

その上で現在の咬頭嵌合位と中心位が一致しているか否 かを再びスプリット・キャストを用いて確かめた結果， 致は見られず現在の咬頭嵌合位と中心位の間にずれが生じ ていることが示された(図11，12).

また，咬合器上において咬合接触を調べると，右上 4 番 に早期接触が確認され，主訴である「右上 4 番の問題」に 咬合が関与しているのは間違いないと判断した(図13). 


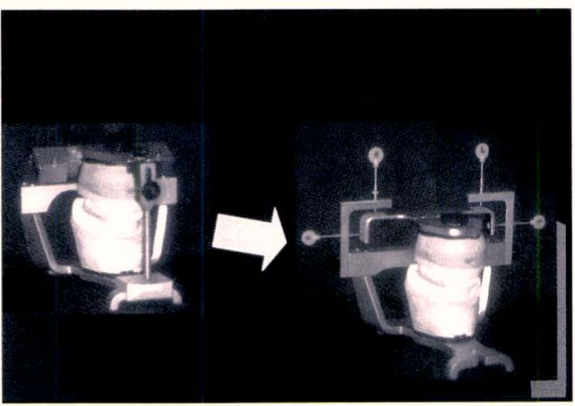

図14 ベリチェック・インストゥルメント

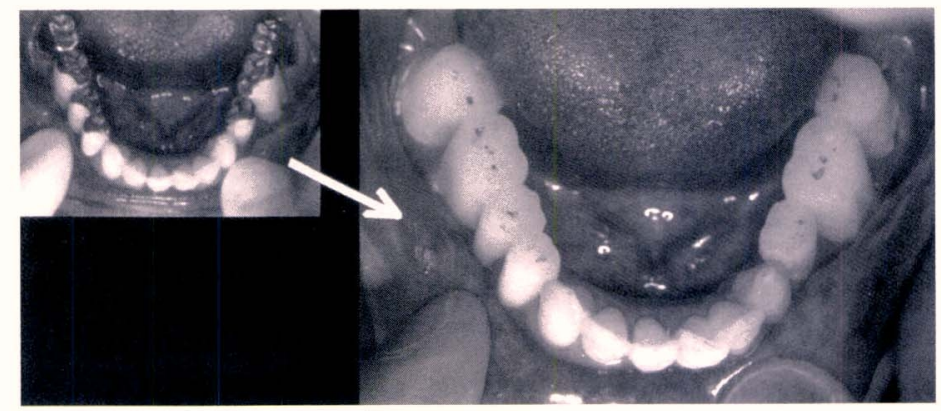

図17 下顎臼歯部をテンポラリークラウンに置き換える

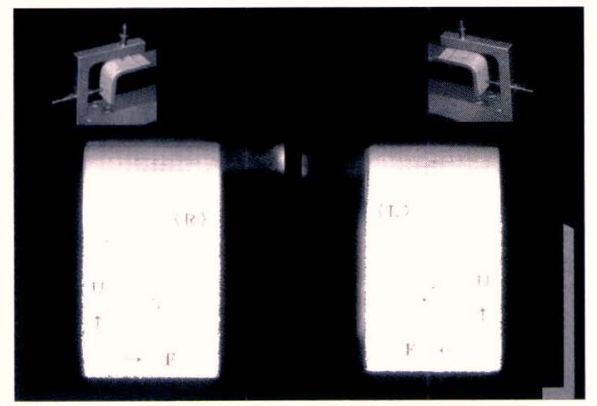

図 15 顆頭相当位.

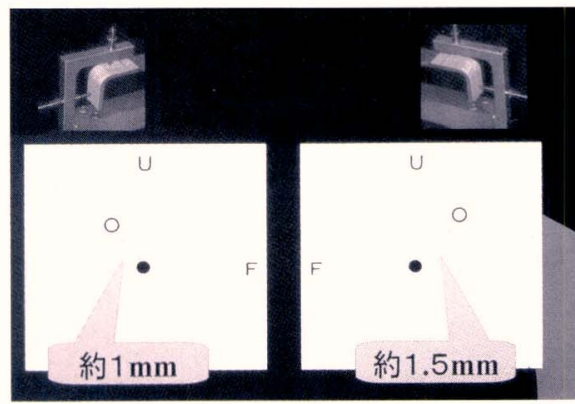

図16 顆頭相当位 (座標図).

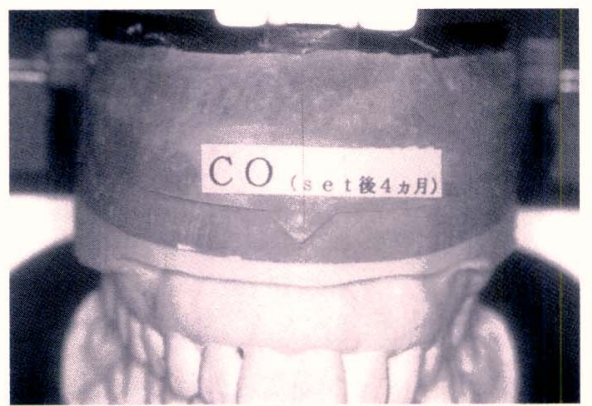

図18 再評価. 適正な下顎位が再現されたか スプリット・キャストを用いて確かめる。
次に，現在の咬頭嵌合位では下顎がどの方向にどれだけ 変位しているかスプリット.キャストではわからなかった ため，この疑問を解消すべくデナー社のベリチェック・イ ンストゥルメントを使用することとした。

この装置は本来，日常臨床ではわかりにくかった顎関節 内に拈ける顆頭の位置を顆頭相当位として座標の形で表現 することをめざした装置である。また使用にあたっては複 雑な操作を必要としないため積極的に日常臨床に取り入れ ることができると考えている(図14).

黑点は中心位，赤点 (白点) は咬頭嵌合位. 写真ではわ かりにくいため座標図をあわせて提示する (図15，16).

上下前後的には，右側で約 $1 \mathrm{~mm}$ 左側では約 $1.5 \mathrm{~mm}$ 咬頭 嵌合位において顆頭相当位が変位しているのが確認され た。

以上の結果より, 症例 1 ほどのあきらかな变位は見受け られないが,この症例においても実は「顆頭の変位を伴っ た低位咬合」であることが確認できた。

咬合調整に際しては削るべきか足すべきか思案した結 果，右上 4 番が生活歯であることや，上顎前歯の審美的改 善のためLOT (Limited Orthodontic Treatment) 後に再修復を 予定していることなどを踏まえ, 患者と相談の上, 下顎臼 歯部を再修復することとした。
いったん下顎臼歯をテンポラリークラウンに置き換え， 下顎位の安定に配慮しながら注意深くポステリア・サポー トの回復をおこなうこととした(図17).

一見，咬合面の形態に大きな変化は認められないが, 4 カ月後再びスプリット・キャストを用いて, 修復後の下 顎位の再評価を行うと, 低位咬合は改善され中心位と咬頭 嵌合位が一致した形でポステリア・サポートの回復ができ たことが確認できた(図18，19).

再修復後約 2 力月で右上 4 の動摇は劇的に消失し, 約一 年後のX線像上においては白線も明暸になり近心側の歯槽 骨にも変化が生じてきている(図20).

現在術後約 4 年が経過しているが，歯槽骨に問題の発生 したことを疑わせるような所見は見受けられない。

\section{まとめ}

二つの症例は共に低位咬合という問題を抱えており，ポ ステリア・サポートを回復することで問題は解消したが, 後者のように一見咬頭嵌合位がしつかりしているように思 われる場合に，特に咬合診断の役割は重要であり，もし下 顎位をどう捉えるか判断を誤れば術後経過は大きく変わっ てしまったと考えられる。

今日，歯牙及び歯周環境の改善を目的としたさまざまな 

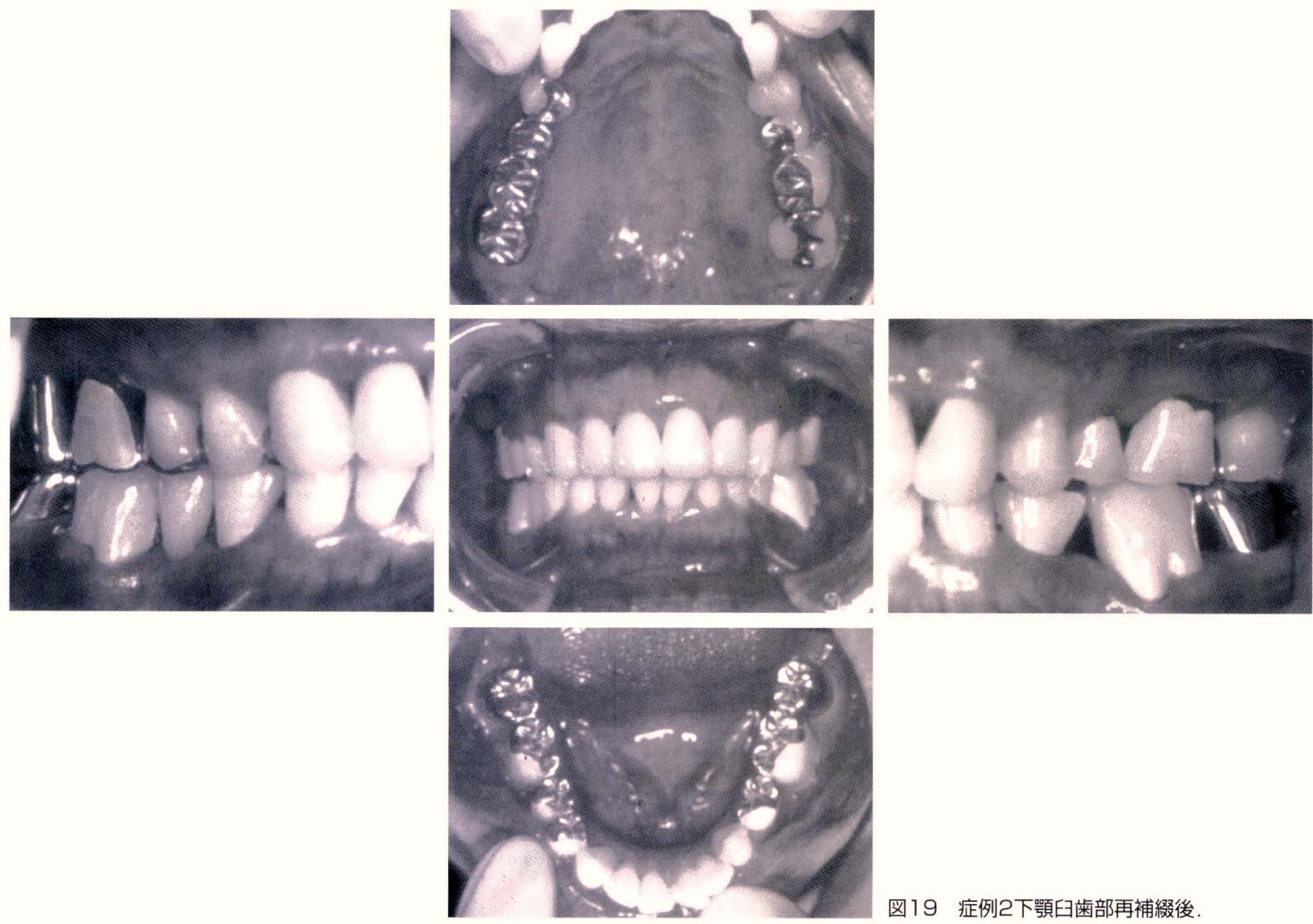

図19症例2下顎臼歯部再補緅後.
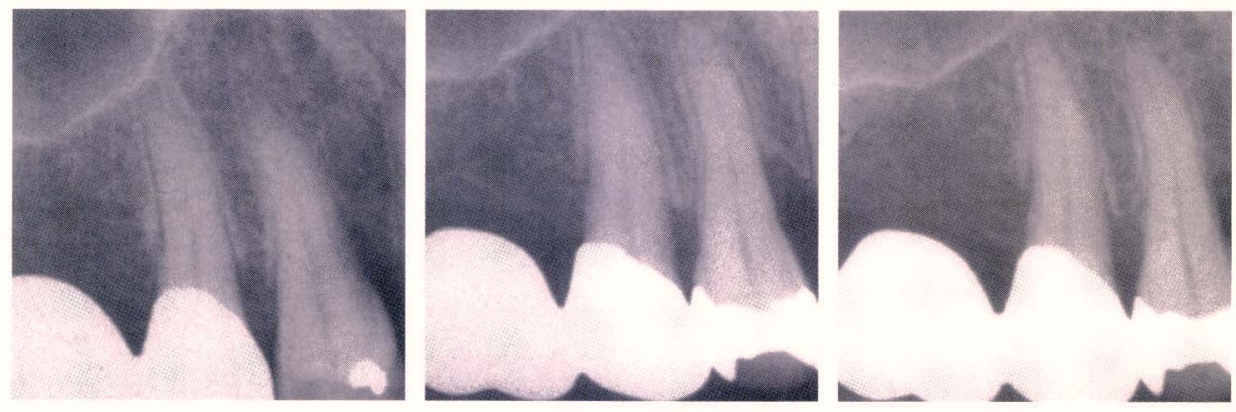

図20 歯槽骨の変化. 左 : 術前, 中 : 術後 1 年, 右 : 術後4年.

新しい治療方法が生み出され，以前にもまして良好な術後 経過を期待することは容易となってきているが，治療方法 が高度になればなるほど，それぞれの処置の予後をしっか り支えるものとして「適正な下顎位」や「ポステリア・サ ポート」という言葉のもつ意味はより重要になっていくと
思われる。

あえて反省点の多い症例 1 を提示させていただいた意義 もふまえ, 本症例のような患者に対する現在の当院の取り 組み方をご理解いただきたい. 